\title{
Research on Problems and Countermeasures of Innovation and Entrepreneurial Education Management
}

\author{
Shanshan Sun \\ Jilin Institute of Chemical Technology, No.45, Chengde Street, Longtan District, Jilin City, Jilin \\ Province, China \\ sunshanshan_jlict@163.com
}

\begin{abstract}
Keywords: Colleges; Innovation and entrepreneurship education; Double-strength strategy, College students
\end{abstract}

\begin{abstract}
The economic growth mode driven by innovation as the main driving force under the new normal of economy requires universities to focus on cultivating innovative high-quality talents. Deepening the innovation and entrepreneurship education in universities is an inevitable measure to achieve this goal. Based on the investigation of the status quo of the implementation of innovation and entrepreneurship education in colleges and universities, we can see that despite the significant progress in the implementation of innovation and entrepreneurship education in colleges and universities, there are not enough new ideas in education, the lack of pertinence of curriculum systems and personnel training models, shortage of teachers, and rigid management of education. There are many problems such as the harsh entrepreneurial environment and failure to fully mobilize the subjective initiative of students. To this end, it is necessary to establish a scientific education concept, clarify the objectives of personnel training, improve the education curriculum system, optimize education and teaching models, carry out extensive practical activities to stimulate innovation and entrepreneurial enthusiasm, strengthen the construction of teaching staff, and improve education and management mechanisms.

In order to greatly enhance the overall quality of contemporary college students, our country's colleges and universities' interests emphasize the cultivation of students' innovative spirit, entrepreneurial awareness and innovation and entrepreneurship, and lay a solid foundation for the students' sustainable development throughout their lives. In the new economic norm, the economic growth mode driven by innovation as the main driving force requires the deepening of the innovation and entrepreneurship education reform, the promotion of high-quality economic and social development in China, and relieving the long-standing relatively grim employment situation. In 2015, the General Office of the State Council issued the "Implementation Opinions on Deepening the Reform of Innovation and Entrepreneurship Education in Colleges and Universities", which highlighted the importance of innovation and entrepreneurship education reform in colleges and universities, and established a sound innovation and entrepreneurship education system with Chinese characteristics for 2020, and cultivated high-quality innovations. The overall goal of talents is laid.
\end{abstract}

\section{The Significance of Implementing Innovation and Entrepreneurship Education in Universities in China}

The Inevitable Requirements for the Development Trend of Higher Education. For the first time, Stanford University in the United States has proposed an education concept that encourages students and entrepreneurs to start businesses, and has established the launch of the world's first research center - the entrepreneurship education curriculum research center. The proportion of innovation and entrepreneurship education in the education system of developed countries accounts for the fact that college students' innovation and entrepreneurship education plays a leading role in the reform of contemporary higher education.

Under this trend of the times, China has responded positively to innovation and entrepreneurship education in colleges and universities. As early as in June 1999, China's "Decision on Deepening Education Reform and Promoting Quality Education in an All-round Way" clearly stated: "Higher 
schools should pay attention to cultivating college students' innovative ability, practical ability and entrepreneurial spirit, and generally improve the humanistic quality and scientific quality of college students"

The Urgent Need for the Development of Knowledge Economy and Socio-Economic Transition. In the era of knowledge economy, innovation has become a core power source for the development of the global economy. The reform of higher education in China regards college innovation and entrepreneurship education as a new form and concept of education in the concept of talent education in colleges and universities. 'It spreads widely and takes it as a major new model of talent cultivation to meet the urgent need for talent in the age of knowledge economy. Demand and respond to the corresponding challenges brought about by the new technological revolution. National knowledge, scientific and technological innovation capabilities and awareness are positively related to the economic growth of a country. In the "12th Five-Year Plan", the state has emphasized that the transformation of China's social and economic growth mode is to take technological innovation and progress as the main support point. The Fifth Plenary Session of the 18th CPC Central Committee emphasized the development of the five major development concepts of the "Thirteenth Five-Year Plan" as the primary guiding concept, placing innovation and entrepreneurship education at the forefront, and innovating as the main line and running through the building of innovative countries. Guided by the two strategies of "prospering China through science and education" and "building a country through science and education" and based on the "three outlines" of science and technology, human resources, and education, we will enhance the ability of university students to independently innovate, cultivate innovative high-quality personnel, and promote economic growth in China. The transformation and the development of education are of strategic significance.

Deepening the Realistic Call for Higher Education Reform. According to a report from the website of the New York Times, a study on whether Chinese schools do a better job than American schools found that Chinese primary and secondary education has trained the most critical students in the world. The critical thinking ability of Chinese students is Loss of advantage during college. This shows that China's rapidly expanding higher education system has certain problems. The major factor causing this problem is the large number of low-quality universities in China. In order to satisfy people's increasing demand for higher education, the government has made and implemented the "enrollment in colleges and universities" decision. By 2015, the number of university students in our country has reached 26.2 million. Obviously, while the scale of higher education is rapidly expanding, the need for connotative development is equally urgent, and the implementation of innovation and entrepreneurship education is the key measure for higher education reform. The reform of innovation and entrepreneurship education in colleges and universities can more effectively promote the transformation and development of applied wood colleges and universities, strengthen the comprehensive quality, innovation awareness and critical thinking ability of college students' innovation and entrepreneurship, which lays a solid foundation for implementing innovation-driven development strategies for the country.

\section{The Problems Existing in the Innovation And Entrepreneurship Education for College Students in China}

The level of innovation and entrepreneurship education of Chinese college students is in the primary stage. This is closely related to China's economic development level, traditional culture concept, higher education level, personnel training system and capital risk awareness. There are many problems in innovation and entrepreneurship education.

The Lack of Idea of Entrepreneurship Education. China's entrepreneurial education started late. In 1998, the first "Entrepreneurship Plan Competition" held by Tsinghua University opened the curtain for entrepreneurship education activities for college students. Under the influence of traditional concepts, most college students and parents pursue stable and relaxed jobs. Indifferent innovation and entrepreneurship in society and indifferent entrepreneurial atmosphere. At present, the value orientation of China's college entrepreneurship education tends to alleviate the 
employment difficulties of college students, rather than as a means and channel for cultivating outstanding talents, so that the connotation and value orientation of college students' innovation and entrepreneurship education are deviated. Even some colleges and universities entrepreneurship education only serve the entrepreneurial plan competition, only the pursuit of competition results, completely deviated from the idea of innovation and entrepreneurship education. Therefore, the current concept of innovation and entrepreneurship education in our country is insufficient. Entrepreneurship education as a college student should have the concept of quality education has not been recognized and accepted by colleges, teachers, college students and other circles.

Poor Policy Protection. Under the severe employment pressure of college students, the Chinese government has advocated colleges and universities to actively carry out innovation and entrepreneurship education, formulated many supportive policies, encouraged college students to invest in their own businesses, broke through the bottleneck of employment, and formulated many preferential policies to support entrepreneurship. However, the high cost of standardized innovation and entrepreneurship education has not yet received effective government funding support. Government policies are mostly macro-level policies and lack supporting implementation programs. As stipulated in the venture capital, the government requires financial institutions to increase support for college students' venture capital, including loan interest rate concessions. However, there are no specific requirements on the micro-levels such as loan conditions and interest rate margins. Pursue profit maximization In view of the success rate of entrepreneurial ventures and the degree of protection for loan recovery, financial companies often set a threshold for entrepreneurial loans for college students, and the loan situation is not optimistic. The formalities for college students to handle innovation and entrepreneurship are complex and there are still provisions in the administrative regulations for industry and commerce that are not conducive to entrepreneurship. China's venture capital industry has developed rapidly, but venture capital for entrepreneurship on college students is almost inexhaustible, the problem of external financing for college students' innovation and entrepreneurship is outstanding, and these have greatly affected the entrepreneurial rate and success rate of college students.

Fragmented Curriculum. The innovation and entrepreneurship education in Chinese colleges and universities is not integrated into the main education system. There is no clear professional orientation. The scattered characteristics of innovation and entrepreneurship courses completely lack the rigor and systemic nature of a discipline. Innovation and entrepreneurship courses are only represented by series of lectures such as "employment guidance" or "career planning". There is no independent system of entrepreneurship courses. Even the lectures do not have systematic planning and fixed arrangements. Innovation and entrepreneurship education lectures and extra-curricular activities. This form of amateur education is merely an operational skill level that is not included in the talent development system or even out of touch with professional education. The creativeness, innovation and entrepreneurial ability of university students are not as clear and specific as their operational skills. Its cultivation must be gradually nurtured through the cultural spirits embodied in humanities, sciences and other aspects of knowledge. Only in this way can the hidden and subtle influences be achieved. It is not a day. The merits of entrepreneurship education should be rooted in professional education, integrated into the personnel training system, and infiltrated into all aspects of teaching, which involves the deepening of the reform of the personnel training model and student management system.

Lack of Teachers. The university's innovation and entrepreneurship education requires a wide range of knowledge, practicality, and action-oriented. The experience guided by practical experience in the curriculum is more important than the traditional form of classroom instruction. Therefore, there is a high demand for entrepreneurship education and teachers, which is also innovation and entrepreneurship education. The key to success or not. Entrepreneurial education teachers need comprehensive theoretical knowledge, rich entrepreneurial management experience, and innovative teaching methods. There are mainly three kinds of sources of teachers for innovation and entrepreneurship education in universities in China. There are three types of administrators: administrative personnel engaged in employment management, teachers of related majors, or 
political counselors. The vast majority of teachers have basically no entrepreneurial experience and lack of corporate management practices. Some teachers have only been trained after short-term training, and they are unable to shape their entrepreneurial awareness and entrepreneurial qualities. Some colleges and universities have hired part-time teachers with rich practical experience, such as well-known entrepreneurs, successful entrepreneurs, etc., but colleges and universities generally have inadequate guarantees in terms of institutional guarantees and financial support. Teaching experience of part-time teachers is lacking, and the teaching effect of innovation and entrepreneurship education has not been achieved.

Weakness in Entrepreneurship Practice. Entrepreneurial practice is the most advanced level of entrepreneurship education. Entrepreneurial practice can promote the overall quality of entrepreneurs. Entrepreneurship practice is also an important way to improve the effectiveness of innovation and entrepreneurship education in colleges and universities. China's innovation and entrepreneurship education is in its infancy, and the practice link in entrepreneurship education is very weak. Most colleges and universities lack investment in entrepreneurship education. The establishment of entrepreneurship practice bases has not paid enough attention. These weak links have led to the practice of entrepreneurship education. College students' contact and mastery of entrepreneurship practices are very superficial. Coupled with the old teaching methods and indoctrinative teaching methods of entrepreneurial education, it is impossible to arouse the creativity of university students, and to burn the passion for exploration and innovation.

\section{Optimizing the College Innovation and Entrepreneurship Education}

Establish a scientific Education Concept and Clarify the Goal of Personnel Training. Under the dual-invasion background, colleges and universities should transform the traditional academic talent cultivation into application-oriented innovative talents training models, and cultivate personnel with the innovative thinking and entrepreneurial awareness. In the process of innovation and entrepreneurship education, the maker culture is integrated into related curriculum systems to form advanced entrepreneurial talents that combine the spirit of creating a customer, innovative thinking, and entrepreneurial awareness.

The way out of China's economy is innovation. Colleges and universities must integrate the idea of innovation and entrepreneurship education into education and education, and focus on the promotion of reform and innovation. It is required that the orientation of education in colleges and universities must be transformed from a skill-based education to a comprehensive quality education.

Innovation and entrepreneurship cultivation of talent is ultimately to enter the society, and serve the community, colleges and universities to increase the proportion of humanistic quality courses to help students establish a correct outlook on life, world outlook, values, science and technology curriculum skills to develop students skills training at the same time Strengthen the education of talents, organically integrate humanistic quality courses and science and technology courses, and promote the overall quality of college students. The colleges and universities combine the school's orientation and actual conditions to update the concept of higher education, pay attention to the students' inner innovation, entrepreneurship, and awareness, and effectively combine innovation education, entrepreneurship education, professional education, recreation education, and practical education to form a comprehensive education talent. Training mode.

\section{Improve the Educational Curriculum System, Optimize the Educational Model}

We will deepen the reform of innovation and entrepreneurship education in colleges and universities, and regard the construction of the innovation and entrepreneurship education curriculum system as the core content of the reform. Efficient innovation and entrepreneurship teaching mode is set up, and a comprehensive system of courses enables the students to inspire innovation, explore the potential of innovation, and enhance the ability to innovate and innovate. The innovation and entrepreneurship education is infiltrated into different disciplines and professional teaching, so that general education and professional education can be organically combined, and the two form a supportive and leading relationship. The establishment of business elective courses, the use of specialized teachers to teach entrepreneurial skills for students, and 
current events provide students with the current trends in China's entrepreneurship and some of the district's policy financial support for college students. In the era of Internet+education, we will increase the use of online platforms to develop online courses, such as: Moomin online education, WeChat platform education, and so on.

Extensive Practical Activities to Stimulate Innovation and Entrepreneurial Enthusiasm. Colleges should promote collaboration between personnel training and social needs, understand the development of new industries and new technologies, and form demand-oriented discipline structures and personnel training structures. Entrepreneurship seminars are held to invite successful entrepreneurs to share entrepreneurial success stories among undergraduates, especially those with entrepreneurial awareness and entrepreneurial potential. Develop practical activities in general and build platforms for innovation and entrepreneurship education practice activities, such as: Innovation and entrepreneurship simulation training--simulation and training of business management, market development and marketing training, and team cooperation simulation training; and innovation and entrepreneurship comprehensive practice platform--undergraduate entrepreneurship competition ( Entrepreneurs create companies independently, recruit teams, etc.). Strengthen the cooperation between universities and enterprises. Students participate in the mentor or the company's projects, and truly implement the road of cooperation between industry, universities and research institutes, so that both universities and enterprises can maximize the efficiency of resource utilization. The government adopts the model of cooperation between government, industry and research, and clearly stipulates that relevant stakeholders should fully play their respective roles in innovation and entrepreneurship, increase the success rate of entrepreneurship, and truly achieve the basic policy of employment-led employment. The implementation of experiential teaching, through participation in tutors or corporate projects to achieve innovation and entrepreneurship projects, and then take the initiative to dock with the corresponding industry companies.

Strengthen the Construction of Teachers. The teaching staff plays a key role in college students' innovation and entrepreneurship. Colleges and universities should encourage full participation and clarify the responsibility of teachers for innovation and entrepreneurship education. Innovation and entrepreneurship education requires not only research-oriented teachers, but also professional entrepreneurial talents as specialized instructors. Therefore, all colleges and universities actively strengthen contacts and combine full-time and part-time work with a strong professional teaching staff. Establish a sound long-term mechanism for school-industry cooperation. The school regularly quantifies the corresponding professional teachers to practice learning in the enterprise. This not only enables teachers to create a theoretical knowledge system of innovation and entrepreneurship education, but also effectively integrates theory and practice, and improves their own innovation. Entrepreneurial awareness and ability lay a solid foundation for entrepreneurship and student entrepreneurship. Reforming the system of assessment and appraisal of teachers, focusing on improving the evaluation of professional and technical titles and performance appraisal standards, strengthening the evaluation of innovation and entrepreneurship education, and increasing the support for the construction of innovation and entrepreneurship teachers from the aspects of teaching assessment, job title assessment, and incentive mechanisms. Strength, such as the incentive mechanism, can be combined with the actual improvement of the school's talent grant and key post special allowance system to implement the post allowance for innovation and entrepreneurship education teachers.

Improve the Education Management Mechanism. In recent years, innovation and entrepreneurship education in colleges and universities has been continuously strengthened, but there are also some problems that cannot be ignored in management. All colleges and universities need to establish a sound student entrepreneurship guidance department, and even set up a special management department and research department based on successful cases. The establishment of a sound information service system can provide students with real-time information on national policies, market trends, etc., and provide continuous assistance for self-creating students. Universities and colleges actively develop entrepreneurial training courses that suit the 
characteristics of students according to their own regional characteristics, and guide college students to identify entrepreneurial opportunities in light of regional development and industry needs. In addition, colleges and universities need to integrate funds, optimize expenditures, and improve financial management so as to provide financial assistance to university students in various forms. Finally, colleges and universities and other regions formed concerted efforts to strengthen the necessity and importance of propagating innovation and entrepreneurship education, and timely summed up successful experiences throughout the country, enriched the forms of propaganda, and created a positive entrepreneurial atmosphere.

\section{References}

[1] Current situation of innovation and entrepreneurship education in universities in China and research on its reform and development strategy [J]. Mu Yarong.Law System and Society. 2015(27)

[2] Discussion on the Development of Undergraduates' Innovation and Entrepreneurship Education in the New Normal State [J]. Marina. Asian Education. 2015(11)

[3] Problems and Countermeasures in the Integration of Entrepreneurship Education and Professional Education in Universities [J]. Jiang Yangfei. College Education Science. 2014 (04)

[4] Students' innovation and entrepreneurship education system problems and countermeasures[J]. Deng Qizhong,Zhou Zhiqiang. Innovation and Entrepreneurship Education. 2014(01)

[5] Problems and Countermeasures in the Development of Innovation and Entrepreneurship Education in China [J]. Jiang Yan, Li Wen, Wang Liqin, Yang Ye, Cai Changfu. Science and Technology Fields, 2013(11)

[6] Research on the development of innovation and entrepreneurship education in colleges and universities from the perspective of enterprises [J]. Wang Changheng. China Vocational and Technical Education. 2013(06)

[7] Enlightenment of foreign innovation and entrepreneurship education model on Chinese universities [J]. Walnut, Shen Li. China University Teaching. 2013 (02)

[8] Current situation analysis and countermeasure research of innovation and entrepreneurship education for college students[J].ZENG YU,LIU MENG.Northern Economy and Trade. 2013(01)

[9] Development of Entrepreneurship Education in the United States and Its Enlightenment to Entrepreneurship Education in China [M]. Meng Xiangxia, Huang Wenjun. China Higher Education Research. 2012 (10)

[10] Discussion on Innovation and Entrepreneurial Education for Local College Students[J]. Wen Fengan. Educational Theory and Practice. 2011(15) 